\title{
Current challenges and opportunities in treating hypoxic prostate tumors
}

\author{
Declan J. McKenna', Rachel Errington ${ }^{2}$, Klaus Pors ${ }^{3}$ \\ ${ }^{I}$ Biomedical Sciences Research Institute, University of Ulster, Coleraine BT52 1SA, Northern Ireland, UK. \\ ${ }^{2}$ School of Medicine, Cardiff University, Heath Park, Cardiff CF14 4XN, UK. \\ ${ }^{3}$ Institute of Cancer Therapeutics, Faculty of Life Sciences, University of Bradford, Bradford BD7 1DP, West Yorkshire, UK.
}

Correspondence to: Dr. Declan J. McKenna, Biomedical Sciences Research Institute, University of Ulster, Cromore Road, Coleraine BT52 1SA,

Northern Ireland, UK. E-mail: dj.mckenna@ulster.ac.uk

How to cite this article: McKenna DJ, Errington R, Pors K. Current challenges and opportunities in treating hypoxic prostate tumors. $J$ Cancer Metastasis Treat 2018;4:1-13.

\begin{abstract}
Article history:
Received: 31 Oct 2017

First Decision: 4 Dec 2017

Revised: 25 Dec 2017

Accepted: 25 Dec 2017

Published: 1 Mar 2018
\end{abstract}

Key words:

Hypoxia,

prostate cancer,

hypoxia activated prodrugs,

OCT1002,

AQ4N,

bioinformatics,

DNA damage,

combination therapies

\begin{abstract}
Hypoxia is a well-established characteristic of prostate tumors and is now recognised as a major contributory factor to both tumor progression and increased resistance to therapy. One strategy to target hypoxic tumor cells is the development of hypoxia-activated prodrugs (HAPs), which are activated in low oxygen environments. Several HAPs have been developed but despite encouraging results from preclinical studies many of these have performed disappointingly in clinical trials. In the developing era of precision medicine, it is clear that more strategic deployment of these agents is required, based on reliable methods that can identify patients who will benefit from HAP treatment, either alone or in combination with other drugs. This review discusses the primary limitations of using HAPs to treat hypoxic tumors and explains how these challenges can be addressed. In particular, it emphasises the importance of tumor imaging and identification of reliable biomarkers for measuring hypoxia and monitoring cellular response to treatment in individual patients. Developing predictive assays for clinical use will be paramount in demonstrating the patient impact and effectiveness of HAPs for personalised medicine.
\end{abstract}

\section{INTRODUCTION}

A large body of evidence now exists to show that hypoxia occurs in most solid tumors and can have a major influence on treatment response ${ }^{[1-3]}$. Under hypoxic stress, cells respond in a number of ways which are primarily mediated through hypoxia-inducible factors $(\mathrm{HIFs})^{[4]}$. When cellular oxygen levels are normal HIFa subunits are degraded by the proteasome following hydroxylation by prolyl hydroxylase domain (PHD) proteins and poly-ubiquination by the von Hippel-Lindau tumor suppressor, which is the substrate recognition component of an E3-ubiquitin ligase. When

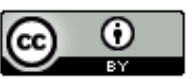

This is an open access article licensed under the terms of Creative Commons Attribution 4.0 International License (https://creativecommons.org/licenses/by/4.0/), which permits unrestricted use, distribution, and reproduction in any medium, as long as the original author is credited and the new creations are licensed under the identical terms.

For reprints contact: service@oaepublish.com

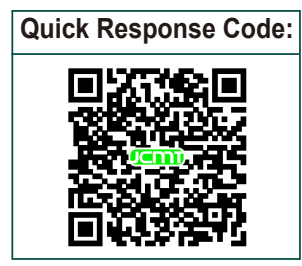




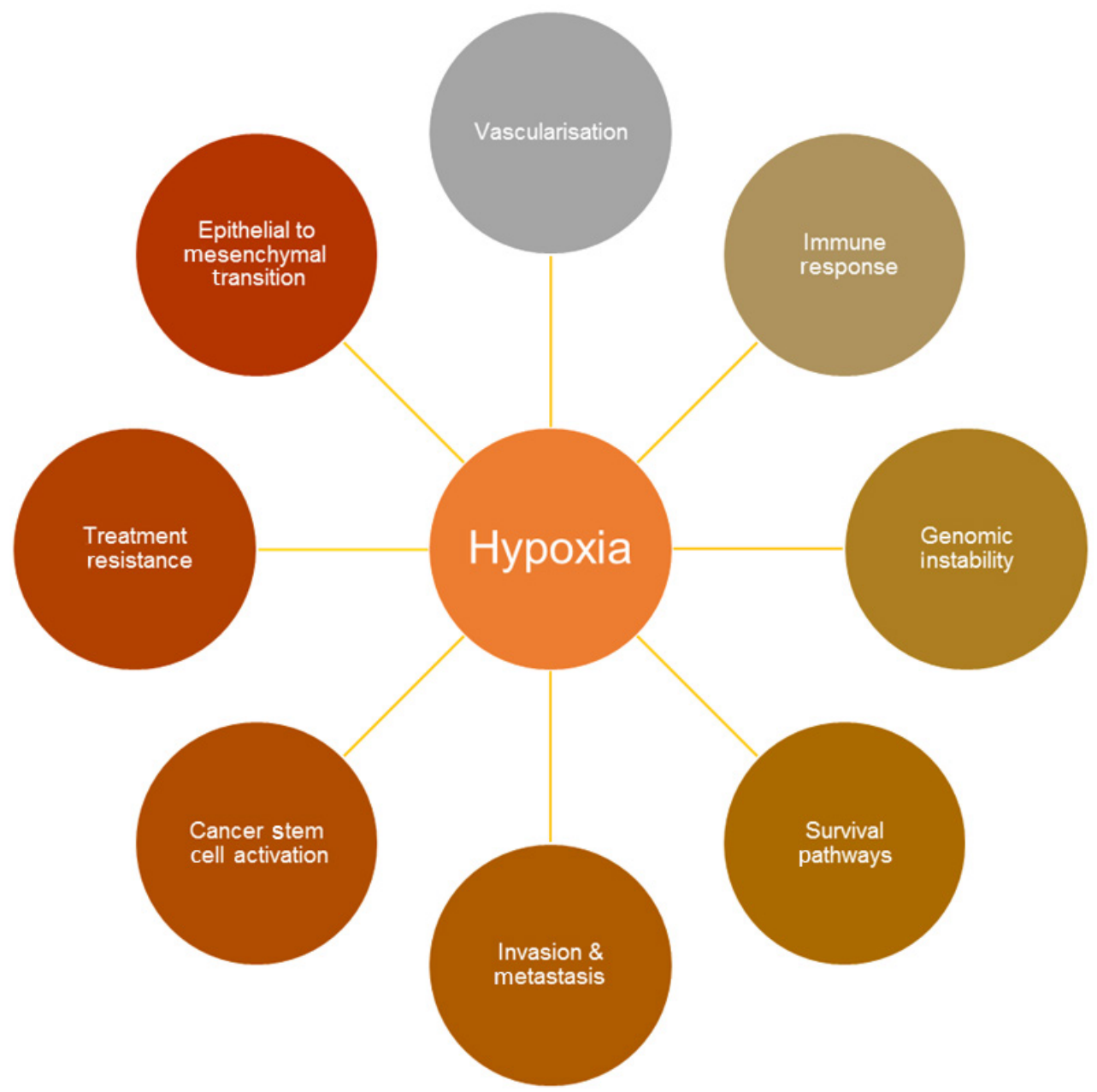

Figure 1: Hypoxia impacts upon a number of important pathways which can promote tumor growth and progression

oxygen levels are low, the PHD enzymes become inactive, thereby reducing the degradation of HIFa. The stabilised HIFa molecules translocate to the nucleus, form dimers with constitutively expressed HIF $\beta$ subunit, and bind to DNA to initiate gene transcription in response to the hypoxic environment ${ }^{[5]}$. HIF-independent hypoxia responses have also been described, including adaptive mechanisms regulated by mTOR signalling ${ }^{[6]}$, p38 MAPK ${ }^{[7]}$ and NF-KB ${ }^{[8]}$. It is therefore clear that a complex network of cellular and molecular signalling occurs when cells are exposed to hypoxic stress ${ }^{[9,10]}$.

This is important during cancer progression, because accelerated proliferation of cancer cells can result in abnormal vascularization, unstable blood flow and reduced $\mathrm{O}_{2}$ diffusion within a solid tumor, causing hypoxic regions to develop. This is significant because tumor hypoxia has been shown to cause numerous molecular and genetic changes within cells which promote cell survival and drive tumor development [Figure 1] ${ }^{[9,10]}$.
Table 1 shows the reported values from different studies on various cancers, demonstrating that the oxygen level in normal tissues can vary from approximately 4\%-6\% oxygen depending on the tissue; the normal prostate has one of the lowest reported median oxygen levels $(\sim 4 \%)^{[3]}$. Normal physiological stress responses to a reducing level of oxygen probably occur between $1 \%$ and $3 \%$ although the exact level is difficult to define and may well depend on multiple factors including the tissue under investigation. In tumors, oxygen levels are frequently reported at well below $1 \%$ indicating that tumor cells are exposed to severe hypoxic stresses. The proportion of the cells exposed to these extreme hypoxic stresses will vary across the tumor and can also be modified by responses to treatment.

Untreated prostate tumors are known to be very hypoxic $(\sim 0.3 \% \text { oxygen })^{[3,4]}$, which is $>12$ times lower than oxygen levels found in the normal prostate ${ }^{[3,11]}$. Prostate tumor hypoxia has been implicated as a causative factor in malignant progression ${ }^{[12,13]}$, genetic 
Table 1: Reported values of the partial $\mathrm{pO}_{2}$ in human tumors and corresponding normal tissues

\begin{tabular}{|c|c|c|c|c|c|c|c|c|}
\hline Tumor type & $n$ & $\begin{array}{l}\text { Median tumor } \\
\mathrm{pO}_{2}\end{array}$ & $\begin{array}{c}\text { Median \% } \\
\text { oxygen }\end{array}$ & $n$ & $\begin{array}{c}\text { Median } \\
\text { normal } \\
\text { tissue } \mathrm{pO}_{2}\end{array}$ & $\begin{array}{c}\text { Median } \% \\
\text { oxygen }\end{array}$ & $\begin{array}{c}\text { Fold } \mathrm{pO}_{2} \\
\text { decrease }^{\mathrm{a}}\end{array}$ & Reference \\
\hline Brain (6) & 104 & 13 & 1.7 & 104 & 26 & 3.4 & 2 & [11] \\
\hline \multirow{4}{*}{$\begin{array}{l}\text { Head and neck cancer } \\
\text { (13) }\end{array}$} & 592 & 10 & 1.3 & & ND & 5.9 & 4.5 & [11] \\
\hline & 30 & 12.2 & 1.6 & 14 & 40 & 5.3 & 3.3 & [88] \\
\hline & 23 & 14.7 & 1.9 & 30 & 43.8 & 5.8 & 3 & [89] \\
\hline & 65 & 14.6 & 1.9 & 65 & 51.2 & 6.7 & 3.5 & [90] \\
\hline \multirow[t]{2}{*}{ Lung cancer } & 6 & 14.3 & 1.9 & & ND & 5.6 & 3 & [91] \\
\hline & 20 & 16.6 & 2.2 & & 42.8 & 5.6 & 2.6 & [92] \\
\hline Breast cancer (10) & 212 & 10 & 1.3 & 212 & 52 & 6.8 & 5.2 & {$[11,93]$} \\
\hline \multirow[t]{2}{*}{ Pancreatic cancer } & 7 & 2.7 & 0.4 & 7 & 51.6 & 6.8 & 19.1 & [94] \\
\hline & 1 & 2 & 0.3 & & & & 22.7 & [95] \\
\hline \multirow[t]{3}{*}{ Prostate cancer } & 59 & 2.4 & 0.3 & 59 & 30 & 3.9 & $12.5^{b}$ & [96] \\
\hline & 55 & 4.5 & 0.6 & & ND & & $6.7^{\mathrm{b}}$ & [97] \\
\hline & 10 & 9.4 & 1.2 & 2 & 26.2 & 3.4 & $2.8^{c}$ & [98] \\
\hline Melanoma & 18 & 11.6 & 1.5 & 20 & 40.5 & 5.3 & 3.5 & [99] \\
\hline \multirow[t]{2}{*}{ Rectal carcinoma } & 14 & 32 & 4.2 & & 52 & 6.8 & 1.6 & {$[100]$} \\
\hline & 15 & 19 & 2.5 & & 52 & 6.8 & 2.7 & [101] \\
\hline Sarcoma (14) & 283 & 14 & 1.8 & 283 & 51 & 6.7 & 3.6 & [11] \\
\hline
\end{tabular}

The data in the table is adapted with permission from a review by McKeown (2014). The number of studies included for each tumor type is indicated by the number in the "tumor type" column. Other data are from single studies, as referenced. ${ }^{a}$ Fold reduction of tumor vs. normal tissue is based on all the data presented in the table (except prostate; see below); "fold reduction calculated on contemporaneous measurements in the psoas muscle; "data from a pilot study that included values from the "normal" prostate of two bladder cancer patients. $\mathrm{ND}$ : not determined; $\mathrm{pO}_{2}$ : pressure of oxygen

instability ${ }^{[14]}$, endothelial-to-mesenchymal transition ${ }^{[15,16]}$ and selection of cells with diminished apoptotic potential and a greater invasive potentia|[17,18]. These plethora of changes means that the presence of hypoxia has significant implications for cancer therapy ${ }^{[11,19]}$. Indeed, as far back as the 1950s, it was realised that hypoxia is an underlying cause of resistance to radiotherapy ${ }^{[20,21]}$. Since then it has been consistently shown that high levels of hypoxia significantly correlate with increasing clinical stage and can predict biochemical failure following radiotherapy ${ }^{[22]}$. Recent studies have shown that hypoxic conditions significantly enhances exosome secretion in a HIF-1a-dependent way ${ }^{[23]}$. Exosomes are microvesicles containing a cargo of signature proteins, lipids, nucleic acid and metabolites that can contribute to the remodelling of the tissue microenvironment $[24,25]$. In prostate cancer models they have been shown to mediate angiogenesis, cell stemness and activation of the surrounding tumor stroma ${ }^{[26]}$. Similarly, hypoxia has been linked with increased resistance to chemotherapeutic drugs ${ }^{[27,28]}$. Therefore, hypoxia is clearly a significant obstacle to the effective treatment of tumors, so it is a viable therapeutic strategy to directly target hypoxic tumor cells in an attempt to improve treatment ${ }^{[27,29,30]}$. Although such a strategy has yet to establish clinical acceptance, one of the most promising translational approaches for patient treatment is based on the use of bioreductive drugs ${ }^{[31,32]}$. These are now more commonly known as hypoxia activated prodrugs (HAPs) or, in the case of the metabolically distinct anthraquinonederived compounds, unidirectional HAPs (uHAPs). This review will focus on the therapeutic potential of these compounds in targeting hypoxic tumor cells, although the molecular targeting of hypoxia factors such as HIF is an equally valid strategy for targeting hypoxia and is reviewed elsewhere ${ }^{[30,33]}$.

The concept underpinning the use of HAPs is wellestablished and several recent reviews exist, which we refer to for further understanding ${ }^{[32,33]}$. When oxygen levels are very low HAPs or uHAPs are reduced to covalently-binding active cytotoxins or release DNAdamaging radicals ${ }^{[31,32]}$. Thus the incorporation of a HAP into a treatment regime should be an ideal approach to specifically target tumor cells, particularly as hypoxia is rare in normal tissues ${ }^{[34]}$. Other properties for an effective HAP, discussed throughout this review, include (1) the ability to reach hypoxic cells, (2) pharmacological features which allow it to be metabolised effectively, and (3) exertion of a lasting, targeted effect on the tumor ${ }^{[32]}$. With these in mind several compounds have been developed and tested in vitro, in vivo and in patients with different cancers [Table 2 and Figure 2].

However, although encouraging results have been obtained from preclinical studies many of the HAPs listed in Table 2 have not been realised in clinical trials. Currently, only a few of these molecules are being 
Table 2: HAPs which have been tested in human clinical trials

\begin{tabular}{|c|c|c|c|c|}
\hline Prodrug & Company or institution & Chemical class & Mechanism of cytotoxicity & References \\
\hline Tirapazamine (SR 4233) & SRI International/ $\mathrm{NCl}$ & Aromatic $\mathrm{N}$-oxide & Complex DNA damage & {$[102,103]$} \\
\hline Apaziquone (E09) & Spectrum & Quinone & DNA interstrand crosslink & {$[104,105]$} \\
\hline Evofosfamide TH-302 & Threshold & Nitroaromatic & DNA interstrand crosslink & {$[106-108]$} \\
\hline $\begin{array}{l}\text { Tarloxitinib } \\
\text { TH-4000 }\end{array}$ & $\begin{array}{l}\text { Threshold and University of } \\
\text { Auckland }\end{array}$ & Nitroaromatic & $\begin{array}{l}\text { Pan-HER inhibitor } \\
\text { Tyrosine kinase inhibitor }\end{array}$ & [109] \\
\hline PR-104 & $\begin{array}{l}\text { Proacta and University of } \\
\text { Auckland }\end{array}$ & Nitroaromatic & DNA interstrand crosslink & {$[110,111]$} \\
\hline Banoxantrone (AQ4N) & KuDOS/Novacea & Aliphatic $\mathrm{N}$-oxide & $\begin{array}{c}\text { DNA intercalator and topo II } \\
\text { inhibitor }\end{array}$ & [35] \\
\hline Porfiromycin & Vion Pharmaceuticals & Quinone & DNA interstrand crosslink & {$[112,113]$} \\
\hline $\mathrm{RH} 1$ & CRUK & Quinone & DNA interstrand crosslink & [114] \\
\hline
\end{tabular}

NCI: National Cancer Institute; CRUK: Cancer Research UK; HER: human epidermal growth factor receptor; HAPs: hypoxia-activated prodrugs<smiles>Nc1[nH][n+]([O-])c2ccccc12</smiles>

Tirapazamine<smiles>COCCCCc1cc([N+](=O)[O-])cc([N+](=O)[O-])c1N(CCO)CCBr</smiles>

PR-104<smiles>Cn1c([N+](=O)[O-])cnc1COP(=O)(NCCBr)NCCBr</smiles>

TH-302 (Evofosfamide)<smiles>C[N+](C)(C)CCNc1ccc(NCC[N+](C)(C)[O-])c2c1C(=O)c1c(O)ccc(O)c1C2=O</smiles>

AQ4N (Banoxantrone)<smiles>CO[C@@]12CN(CC3=C(C(=O)C(C)=C(N)C3=O)C1COC(N)=O)CN2C</smiles>

Porfiromycin<smiles>CN1C2=C(C(=O)C=C(N3CC3)C2=O)C(/C=C/CO)C1CO</smiles>

EO9 (Apaziquone)<smiles>CN(C)Cc1c([N+](=O)[O-])ccn1/C=C/C(=O)Nc1cc2c(Nc3ccc(Cl)c(Br)c3)ncnc2cn1</smiles>

TH-4000 (Tarloxotinib)<smiles>CC1=C(N2CC2)C(=O)C(CO)=C(N2CC2)C1=O</smiles>

RH1

Figure 2: Chemical structures of HAPs that have been under clinical evaluation. HAPs: hypoxia-activated prodrugs

actively pursued, whereas the clinical development of others has been discontinued ${ }^{[31,32]}$. It has become clear that future large HAP clinical registration trials need to incorporate biomarkers of hypoxia to identify patients who would benefit from this type of treatment. Furthermore, in some clinical trials involving HAPs, later retrospective analyses were carried out and showed that specific cohorts treated did have a significant survival advantage. Thus, as with many cancer therapies there is a requirement to stratify patients for a number of different factors including importantly hypoxia. As Table 1 shows, there is considerable variation in tumor hypoxia between patients, meaning not every patient will show the same response to HAP therapy. Nonetheless, a proofof-principle study has demonstrated that in patients with different tumor types, AQ4N was activated selectively in hypoxic regions in human solid tumors to $A Q 4$ the hypoxia-activated metabolite of $A Q 4 N$ and a potent DNA intercalator and topo II poison ${ }^{[35]}$. This phase I study, has been vital to the identification of the potential clinical efficacy of this prodrug.

Furthermore, tumor heterogeneity will also mean that not all cancer cells will have the innate capacity to be targeted in the same way or to the same extent, as the HAP may not be effectively metabolised to the same degree across the tumor micro-environment. Another difficult question to address clinically is also whether the reductases that are identified as capable of activating the HAPs in preclinical models are present in all hypoxic cells within a heterogenous tumor. Most HAPs (including nitroaromatics, quinones and benzotriazine di-oxides) are activated via a mechanism that begins with one-electron reduction by flavin-dependent oxidoreductases to generate a metabolite which can be readily back-oxidised during fluctuating oxygen tensions; this might be a 
contributing factor to resistance mechanisms under acute hypoxia but not chronic fractions of solid tumors ${ }^{[31]}$. HAPs such as AQ4N that rely on an aliphatic tertiary amine $\mathrm{N}$-oxide are activated via two-electron reduction that is catalysed by CYP isoforms ${ }^{[36-41]}$ is not oxygen sensitive and hence a more persistent cell killing effect may be observed; the more metabolically stable, deuterated analogue of AQ4N, OCT1002 is described further below.

\section{COMBINATION TREATMENT WITH HAPS}

It is clear from clinical results thus far that an increased understanding of how HAPs are activated in different tumor types is required in order to develop reliable predictors of tumor sensitivity to this type of treatment. Moreover, as with most chemotherapeutic drugs, it is unlikely that monotherapy with any given HAP will prove to be wholly effective. A more realistic scenario is that susceptible tumors can be treated with combinatorial therapy which includes a HAP. In the preclinical setting, enhanced anticancer activity has been demonstrated by combining chemotherapy with HAPs. In prostate cancer, synergistic effect has e.g. been achieved using doxorubicin or docetaxel in combination with $\mathrm{TH}-302$, supporting HAPs with cycle-active chemotherapy to treat aggressive forms of prostate cancer ${ }^{[42]}$.

In a clinical context, several HAPs have been investigated in combination with conventional cytotoxic chemotherapy or radiotherapy ${ }^{[43,44]}$. Although some patients have benefitted from the combination therapy, the results of these trials have at large been disappointing as reflected upon by Hunter et al. ${ }^{[31]}$. However, with the increasing knowledge we have gained, especially over the past decade, perhaps other combination drugs that address molecular targets, oncogenic drivers and exploit DNA damage response (DDR) pathways will pave the way for the next generation of HAPs.

For example, there is evidence to suggest that DDR induced by hypoxia is altered from the classical pathways induced by damaging agents ${ }^{[45]}$. There are possibly several reasons for this and include repression of DNA repair in hypoxic conditions. Treatment is complicated further by several reports indicating that DNA repair under hypoxia is defective or abnormal and hence may not respond to exposure of the bioreduced metabolites of the HAPs that have undergone clinical evaluation.

The complex nature of a heterogenous tumor is likely to result in a number of alterations and include (1) alteration of the catalytic activity of drug-metabolizing enzymes that are responsible for HAP bioconversion, and (2) the DDR may be differently regulated in different types of cells, e.g. a hypoxic cell and a hypoxia-located cancer stem cell. Some evidence indicate that hypoxiainduced DDR under more extreme hypoxia $(<0.1 \%)$ occurs in the absence of detectable single- or doublestrand breaks and in a background of repressed DNA repair (Olcina \& Hammond). In this regard, it could be important in the future to explore how DNA-targeted metabolites derived from HAPs can be used to exploit changes in DDR influenced by hypoxia.

It is likely that the single electron-reduced HAPs could be sensitive to changes in DDR. HAPs such as tirapazamine and PR-104A that are reduced to DNAreactive metabolites via one-electron reduction have been shown to be more potent in cancer cells harbouring DDR pathways that include dysfunctional homologous recombination repair $(\mathrm{HRR})^{[46,47]}$. Exploitation of dysfunctional HRR genes in hypoxic tumors require the discovery of biomarkers that can help to predict a better response to HAPs, however there has been very little systematic effort to discover and fully unravel the potential of such biomarkers ${ }^{[31]}$. This is in part due to the nature of such research, complicated by tumor reoxygenation that often occurs as a result of spontaneous changes in blood flow and therapy with subsequent impact on DDR pathways ${ }^{\left[{ }^{[8]}\right]}$. An example of how improved understanding of the DDR machinery provides an opportunity for combination therapy was demonstrated by Lindquist et al. ${ }^{[49]}$ who investigated the potential for inhibiting DNA double strand break repair in hypoxic cells by targeting DNA-dependent protein kinase (DNA-PK). BCCA621C, a DNA-PK inhibitor was shown to be able to radiosensitize $\mathrm{NCl}-\mathrm{H} 460$ cells under hypoxic but not normoxic conditions using a range of clinically relevant ionising radiation doses. There is also evidence that Chk1, ATM, ATR and poly (ADP-ribose) polymerase (PARP) are affected by hypoxia ${ }^{[48]}$. In regard to the latter, several PARP inhibitors are under clinical evaluation and information from these trials will provide key information on how HAPs could be used in combination with PARP inhibition (PARPi) alone or with additional radiotherapy. Preclinical data have shown that PARPi can be used as a radiosensitizing agent, which may increase the efficacy of radiotherapy in prostate cancer ${ }^{[50]}$. Recently, Hammond and co-workers have shown that olaparib and radiotherapy combination therapy had significant effect in hypoxic lung cancer xenografts but limited efficacy in less hypoxic tumors ${ }^{[51]}$. It is possible this effect was due to hypoxia-induced contextual synthetic cell-killing events ${ }^{[52]}$. The nature of the tumor microenvironment has an impact on treatment 
outcome. Veliparib has been shown to potentiate PC-3 but not DU-145 tumors to radiotherapy, which may be correlated with higher levels of hypoxia in PC-3 tumors compared with DU-145 tumors ${ }^{[53]}$. These studies did not include pharmacokinetics of either olaparib or veliparib and hence the distribution of the PARP inhibitors within the tumor microenvironment is unknown. It is tempting to speculate that improved delivery of the PARP inhibitors to the hypoxic fractions or inclusion of an appropriate HAP could lead to an enhanced therapeutic index.

\section{USE OF OCT1002 TO IMPROVE EXISTING THERAPY}

Research in our own labs have focused on how uHAPs can improve androgen deprivation therapy (ADT) for prostate tumors. Most HAPs are reduced in singleelectron reduction steps, a process which is reversible if oxygen levels increase. However, $A Q 4 \mathrm{~N}^{[54]}$, its deuterated analogue OCT1002 (OncoTherics Ltd) ${ }^{[55]}$ and $\mathrm{AQ4N}$ analogues with potential to covalently adduct DNA/topo $\|^{[56]}$ can be considered uHAPs. These compounds are alkylaminoanthraquinone di$\mathrm{N}$-oxides, which are irreversibly bioactivated via a two-step, two electron reduction to form the reduction products (AQ4 and OCT1001, respectively). These are metabolically stable, highly toxic DNA-affinic reduction products which exist independent of any further change in oxygenation. OCT1002 differs from $A Q 4 N$ through highly selective deuterium substitution of the 12 hydrogen atoms contained within the two $\mathrm{N}$-oxide side chains ${ }^{[5]}$. This results in superior intracellular persistence of the activated form OCT1001, since deuteration slows cytochrome P450 metabolism, alters subcellular localisation and sequestration properties, thereby contributing to an enhanced intracellular persistence of the activated drug as described for other drugs ${ }^{[57,58]}$. Consequently, it is predicted that OCT1002 should be an improved analogue and is therefore under extensive preclinical evaluation.

A recent study has investigated how OCT1002 may be combined with existing therapies for prostate cancer to prevent ADT resistance and progression to castrate resistant prostate cancer (CRPC) ${ }^{[55]}$. It was shown that OCT1002 has a hypoxia-dependent antitumor effect in androgen-sensitive LNCaP prostate tumor xenografts and the effect can be markedly enhanced when combined with bicalutamide, an ADT drug which inhibits androgen signaling by targeting the androgen receptor (AR). The study also showed that it could block significantly the molecular changes caused by bicalutamide alone. This is consistent with previous studies in the same model which showed that bicalutamide induces hypoxia through vascular collapse ${ }^{[15,57]}$ resulting in molecular changes that included evidence of endothelial to mesenchymal transition and increased metastasis to the lungs within 4 weeks ${ }^{[15]}$. These hypoxia-induced responses may help explain why patients treated solely with ADT often relapse; the hypoxic stress selects for resistant cells which survive to establish a tumor with a more malignant phenotype. Along with other studies investigating the link between hypoxia ADT on tumors ${ }^{[59,60]}$, this lends weight to the idea that druginduced hypoxia may in fact drive prostate cancer progression and that HAPs may be a valuable way to address this issue.

This is timely work as the idea of combinatorial drug treatment has gained considerable traction in recent years. In particular, recent results from the CHAARTED ${ }^{[61]}$ and STAMPEDE ${ }^{[62]}$ clinical trials have revealed that use of docetaxel in combination with ADT improved relapse-free survival in patients with high-risk localised prostate cancer, proving that combining ADT with other types of drug can benefit prostate cancer sufferers. Since hypoxia is a major factor in developing ADT resistance, it makes sense to combine ADT with HAPs or uHAPs as a therapeutic strategy. However, as discussed above the absolute requirement for patient derived evidence-led decision making during clinical development of various HAPs demonstrates that translating these compounds into clinically accepted drugs needs careful consideration of tumor micro-environment and related hypoxic status. It requires both improved understanding of the action of these agents, as well as methods with which to clearly identify tumors which will be sensitive to HAPs. We still need improved ways to predict which patients will respond to which drugs. Making the right decisions on whether to use HAPs require increased knowledge about the hypoxic mechanisms which drive prostate cancer progression in order to improve patient stratification in the clinic. This means developing accurate, sensitive ways to identify tumors that are likely to be susceptible to hypoxic targeting.

\section{DETECTION OF PRODRUG CONVERSION AND PREDICTION OF RESPONSES TO HAPS}

The key to ascertaining or indeed stratifying a prostate tumor for sensitivity to hypoxia targeting through HAP treatment requires a multi-pronged approach which has to take into consideration multiple aspects. Importantly this requirement provides an opportunity to bring new technologies and innovations to bear in order to really elucidate the effectiveness of the 
drug from molecular profiling to potentially single cell functional analysis. Thus here we consider approaches aimed at developing novel and functional assays for tumor stratification.

Many hypoxia-targeting small molecules, for example, [(18)F]FAZA, [(18)F]FMISO, [(18)F]EF5, and [(123) I]IAZA, have been shown to accrue selectively in hypoxic cells. These positron emission tomography molecular contrast agents have been extensively applied in clinical hypoxia imaging, including cancer ${ }^{[63]}$. However the outstanding challenge is to multiplex these imaging readouts with the delivery and conversion of prodrug in the same tumor and package the acquisition and analysis algorithms such that they offer pragmatic solutions for advancing our understanding of HAP bioavailability and conversion.

Many bioactive molecules have chromophores ${ }^{[64]}$ thus offering the prospect for tracking target interactions through methods such as steady-state fluorescence readouts, or determining fluorescence quenching properties and fluorescence lifetime measurements for detecting drug tethering to target. Fluorescence life-time and quenching analyses can lead to a unique means for dissecting sub-resolution molecular interactions in situ[65]. For instance, recent spectroscopic investigations show molecular properties of doxorubicin change due to alterations in the local environment, such as when the drug is encapsulated to nanoparticles. Thus we suggest that fluorescence imaging provides a powerful tool for investigating drug delivery in tumor cells and tissue, and further allows for the linking of multi-scalar features of drug design, stability and metabolism together with the complexities imposed by the biological system including tissue penetration and drug-target interactions.

All these fluorescent modalities are very much applicable for the uHAPs such as AQ4N and OCT1002 which are fluorescent due to the anthraquinone chromophore and detectable in vitro and in vivo ${ }^{[55,66]}$ and also retained in tissue even after snap-freezing of xenograft material. Cryosections of frozen xenograft tumor tissue slices were examined for AQ4 fluorescence and distribution by fluorescence microscopy, alongside HPLC/mass spectroscopy analysis ${ }^{[67]}$. To extend the concept further, the efficiency of drug-target interaction of the prodrug is driven by not only pharmacokinetic factors but a host of parallel cellular status and events that are required to elicit the sought pharmacodynamic responses, which are also heterogeneously expressed through the tumor. Hence the requirement for in vivo pharmacodynamics readouts, such as that provided by a truncated 53BP1 double-strand reporter, recently shown to accentuate the approach for in situ single cell analysis of cancer therapeutics ${ }^{[68]}$. Applying this PK-PD linked imaging at the single cell would provide the evidence and mechanisms essential for the development of HAP therapeutic strategies that address changing patterns of target presentation in different cellular microenvironments, and prostate tissue architecture.

\section{BH3 PROFILING TO PREDICT CAPACITY FOR CELL DEATH AT THE SINGLE CELL LEVEL}

The primary action of the AQ4N and OCT1002 metabolites is through DNA damage and subsequently apoptosis. Despite much research into the molecular pathways that regulate cell death, the signalling networks involved are so complex that molecular profiling of key pro-and anti-apoptotic players alone does not provide the predictive capability needed to assess chemo-responsiveness ${ }^{[69]}$. Thus, functional $\mathrm{BH} 3$ profiling would lead to the derivation of cell death fingerprinting, determining the sensitivity thresholds for apoptosis between and within heterogeneous cancer cell populations. The underlying principle of $\mathrm{BH} 3$ profiling is that mitochondrial depolarization or subsequent processes such as BAK/BAX oligomerisation or cytochrome release following $\mathrm{BH} 3$ peptide exposure serves as a functional biomarker for cellular response to pro-apoptotic cues. A recent technology innovation has led to the development and implementation of novel nano-tools (cross-linked stapled peptides) to aid the understanding of apoptotic responses using flow and image cytometry ${ }^{[70,71]}$. Feasibility studies have shown that $\mathrm{BH} 3$-derived peptides alkylated with azobenzene cross-linkers have the ability to induce detectable physiological changes paralleling the early events in apoptotic cell death. The objective now is to establish a validated $\mathrm{BH} 3$-profiling pipeline suitable for sample stratification, using these peptide $\mathrm{BH} 3$ pathway inducers and sensitizers ${ }^{[72]}$. In short, $\mathrm{BH} 3$ profiling provides a functional readout for the primed apoptotic state of a heterogenous population of cells, again which can be directly linked to drug bioreduction and retention at the single cell level.

\section{MOLECULAR PROFILING AND BIOINFORMATIC ANALYSIS}

The drive towards personalised medicine depends on the discovery of biomarkers which can allow molecular stratification of patients. Such information 
is likely to reside in the vast arrays of data detailing the specific genetic characteristics of individual prostate tumors which has been gathered by genomic profiling in recent years. Comprehensive bioinformatics analyses of this data has revealed that a wide molecular diversity exists in human cancer, including prostate tumors (TCGA Network, 2015) [73]. Such tumor heterogeneity may help explain why patients presenting with pathologically similar tumors can have very different responses to the same course of treatment. For example, primary prostate cancers exhibit a wide variability in AR activity, with increased AR-dependent signalling linked to gene mutations in SPOP and FOXA1 (TCGA Network, 2015) ${ }^{[73]}$. Knowing whether a tumor carries these mutations or not can help determine the most appropriate ADT approach for a patient and subsequent tracking of those gene mutations can inform adaptive drug administration. Likewise, knowing the mutational status of the AR gene itself will be critical in helping predict treatment outcome. For instance, enzalutamide cannot bind to an abnormal splice variant of the AR called AR-V7, so patients harbouring this mutation would be unlikely to respond to that particular drug, further emphasising the need to stratify patients by molecular profiles. Indeed, recent research has shown that AR-V7 can be detected in patient blood samples and efforts to validate this screening for clinical application are under way ${ }^{[74]}$.

In a similar manner, it is possible to probe this data for hypoxic markers, allowing researchers to identify key patterns which may allow patient stratification based on hypoxic indices. Hypoxic gene signatures with prognostic potential have been identified in various cancers, such as breast ${ }^{[75]}$, head and neck ${ }^{[76]}$ and laryngeal cancer ${ }^{[77]}$, each study highlighting how expression of genes related to hypoxia can be used to predict outcome. In a prostate cancer setting, a combination of these signatures was subsequently used to categorise hypoxic status of a total of 271 radical prostatectomy samples from two independent cohorts in a study which showed that biochemical relapse was associated with indices of tumor hypoxia, genomic instability, and genomic subtypes based on multivariate analyses ${ }^{[78]}$. Patients with a low percentage of genome alteration and low hypoxia had the best outcome, whereas those with high levels of both measures had the worst. Another study investigated gene expression in prostate tumor biopsies staining positive for hypoxia marker pimonidazole and also identified a signature of hypoxic response genes which correlated with tumor aggressiveness ${ }^{[79]}$. These studies demonstrate the value of genetic profiling of hypoxic status to help stratify patients for treatment, which possibly could include hypoxia targeting in selected groups. As data on clinical samples and patient outcome continues to be collected and archived in data repositories like The Cancer Genome Atlas, these genetic signatures can be continually refined by bioinformatic analysis to identify the most reliable markers of prostate tumor hypoxia.

In addition to tumor analysis, non-invasive biomarkers which can be measured in biofluids are also an attractive option for clinical use. In this regard, microRNAs have generated much excitement as potentially valuable markers of prostate progression and treatment response. These small RNA molecules are much more stably preserved than other RNA species in clinical samples, including fresh and fixed tissues, serum and urine, and can be readily detected using highly specific and sensitive PCR-based assays. miRNAs are important regulators of cell function and many of them are aberrantly expressed in prostate cance ${ }^{[80,81]}$. Of these, miR-210 has been identified as a key regulator of hypoxia ${ }^{[82,83]}$ and has been implicated in prostate cancer progression ${ }^{[84]}$. Significantly, serum levels of miR-210 have been shown to be elevated in prostate cancer patients compared to benign prostatic hyperplasia controls ${ }^{[85]}$, as well as in metastatic CRPC patients who did not respond to treatment ${ }^{[86]}$. The goal is that miR-210 and other related miRNAs can be used as a panel of serum biomarkers that will reflect extent of tumor hypoxia.

It is therefore clear that any strategies for treating prostate cancer must embrace molecular profiling as a means to stratify patients and also monitor response to treatment. Since hypoxia plays such a fundamental role in prostate cancer progression, examining the altered expression of genes involved in hypoxiarelated pathways, as well as network analysis of their interactions, will be an important consideration in developing precision medicine for individual patients.

\section{CONCLUSION}

A major challenge in cancer therapy is to develop therapeutic agents that selectively target tumor cells. One avenue towards the development of more selective cancer therapies is to exploit the unique physiological properties of solid tumors using prodrug approaches. Hypoxia generated as a result of a poor and inefficient neovasculature is a characteristic feature of many solid tumors and is associated with the development of an aggressive phenotype and resistance to radiotherapy and chemotherapy. Whilst problematical for conventional therapies, hypoxia is 
regarded as a valid target for drug development and a series HAPs have been developed over a period of 3040 years with eight HAPs reaching clinical evaluation. Currently, no HAP has reached the market and this is somewhat perplexing given the overwhelming evidence of solid tumors containing significant levels of acute and chronic hypoxia. If patients were molecularly stratified for treatment based on their tumor hypoxia signature including analysis of reductase expression, it is possible that the HAPs in combination with chemotherapy or radiotherapy would have resulted in improved treatment outcomes. Prostate tumors are considerably hypoxic as discussed in this review, which poses some unique challenges to effective treatment of aggressive forms of this disease with standard therapies such as docetaxel and/or radiotherapy. Clinical trials carried out with $A Q 4 N$ have been promising, demonstrating safe administration of a UHAP that rapidly distributes throughout the body and penetrates into hypoxic regions where it is bioreduced to a persistent DNA-affinic topo II-targeting metabolite. The deuterated AQ4N analogue OCT1002 offers great potential in the treatment of prostate cancer, for example in the combination with ADT. In prostate cancer, uHAPs could also be used in combination with PARP1 inhibitors in patients whose tumors harbour DDR deficiencies. Much progress is being made on how best to utilise PARP1 inhibitors but prior analysis of tumor heterogeneity and target expression is vital for clinical success. For example, a recent phase 2 trial that concerned patients with metastatic prostate cancer benefitted from wholeexome sequencing and transcriptome analysis on DNA from fresh-frozen tumor-biopsy samples prior to treatment. In this study, understanding of DNA defects enabled clinicians to select patients suitable for the PARP inhibitor olaparib to ensure better treatment outcome ${ }^{[87]}$. Finally, the emergence of genetic and hypoxic signatures and the ability to image and analyse the heterogeneity of prostate tumors provides new opportunities for employing HAPs and uHAPs in combination with molecularly-targeted agents and/or radiotherapy.

\section{DECLARATIONS}

\section{Authors' contributions}

The authors contributed equally to the manuscript writing and editing.

\section{Financial support and sponsorship \\ None.}

\section{Conflicts of interest}

Professor Rachel Errington is a co-inventor of OCT 1002
(New compounds and uses thereof [CA2881324A1]) and non-executive director of Biostatus Ltd which is the current assignee. Rachel Errington is a shareholder of Oncotherics Ltd.

\section{Patient consent}

Not applicable.

\section{Ethics approval}

Not applicable.

\section{Copyright}

(C) The Author(s) 2018.

\section{REFERENCES}

1. Moeller BJ, Richardson RA, Dewhirst MW. Hypoxia and radiotherapy: opportunities for improved outcomes in cancer treatment. Cancer Metastasis Rev 2007;26:241-8.

2. Rohwer N, Cramer T. Hypoxia-mediated drug resistance: novel insights on the functional interaction of HIFs and cell death pathways. Drug Resist Updat 2011;14:191-201.

3. McKeown SR. Defining normoxia, physoxia and hypoxia in tumoursimplications for treatment response. Br J Radiol 2014;87:20130676.

4. Balamurugan K. HIF-1 at the crossroads of hypoxia, inflammation, and cancer. Int J Cancer 2016;138:1058-66.

5. Bruick RK, McKnight SL. A conserved family of prolyl-4hydroxylases that modify HIF. Science 2001;294:1337-40.

6. Tarrado-Castellarnau M, de Atauri P, Cascante M. Oncogenic regulation of tumor metabolic reprogramming. Oncotarget 2016;7:62726-53.

7. Luo F, Shi J, Shi Q, Xu X, Xia Y, He X. Mitogen-activated protein kinases and hypoxic/ischemic nephropathy. Cell Physiol Biochem 2016;39:1051-67.

8. D'Ignazio L, Bandarra D, Rocha S. NF-kappaB and HIF crosstalk in immune responses. FEBS J 2016;283:413-24.

9. Muz B, de la Puente P, Azab F, Azab AK. The role of hypoxia in cancer progression, angiogenesis, metastasis, and resistance to therapy. Hypoxia (Auckl) 2015;3:83-92.

10. Rankin EB, Giaccia AJ. Hypoxic control of metastasis. Science 2016;352:175-80.

11. Vaupel P, Hockel M, Mayer A. Detection and characterization of tumor hypoxia using pO2 histography. Antioxid Redox Signal 2007;9:1221-35

12. Rudolfsson $\mathrm{SH}$, Bergh A. Hypoxia drives prostate tumour progression and impairs the effectiveness of therapy, but can also promote cell death and serve as a therapeutic target. Expert Opin Ther Targets 2009; 13:219-25

13. Tsai YP, Wu KJ. Hypoxia-regulated target genes implicated in tumor metastasis. J Biomed Sci 2012;19:102.

14. Taiakina D, Dal Pra A, Bristow RG. Intratumoral hypoxia as the genesis of genetic instability and clinical prognosis in prostate cancer. Adv Exp Med Biol 2014;772:189-204.

15. Byrne NM, Nesbitt H, Ming L, McKeown SR, Worthington J, McKenna DJ. Androgen deprivation in LNCaP prostate tumour xenografts induces vascular changes and hypoxic stress, resulting in promotion of epithelial-to-mesenchymal transition. Br J Cancer 2016;114:659-68

16. Li MC, Wang YX, Luo Y, Zhao JH, Li Q, Zhang J, Jiang 
YG. Hypoxia inducible factor-1 alpha-dependent epithelial to mesenchymal transition under hypoxic conditions in prostate cancer cells. Oncol Rep 2016;36:521-7.

17. Butterworth KT, McCarthy HO, Devlin A, Ming L, Robson T, McKeown SR, Worthington J. Hypoxia selects for androgen independent LNCaP cells with a more malignant geno- and phenotype. Int J Cancer 2008;123:760-8.

18. Graeber TG, Osmanian C, Jacks T, Housman DE, Koch CJ, Lowe SW, Giaccia AJ. Hypoxia-mediated selection of cells with diminished apoptotic potential in solid tumours. Nature 1996;379:88-91.

19. Ranasinghe WKB, Baldwin GS, Bolton D, Shulkes A, Ischia J, Patel O. HIF1 alpha expression under normoxia in prostate cancer-which pathways to target? J Urol 2015;193:763-70.

20. Gray LH, Conger AD, Ebert M, Hornsey S, Scott OC. The concentration of oxygen dissolved in tissues at the time of irradiation as a factor in radiotherapy. Br J Radiol 1953;26:638-48.

21. King HW, Michael MZ, Gleadle JM. Hypoxic enhancement of exosome release by breast cancer cells. BMC Cancer 2012;12:421.

22. Turaka A, Buyyounouski MK, Hanlon AL, Horwitz EM, Greenberg RE, Movsas B. Hypoxic prostate/muscle PO2 ratio predicts for outcome in patients with localized prostate cancer: long-term results. Int J Radiat Oncol Biol Phys 2012;82:E433-9.

23. Zhang W, Zhou X, Yao Q, Liu Y, Zhang H, Dong Z. HIF-1-mediated production of exosomes during hypoxia is protective in renal tubular cells. Am J Physiol Renal Physiol 2017;313:F906-F13.

24. Thery C, Zitvogel L, Amigorena S. Exosomes: composition, biogenesis and function. Nat Rev Immunol 2002;2:569-79.

25. Ramteke A, Ting H, Agarwal C, Mateen S, Somasagara R, Hussain A, Graner M, Frederick B, Agarwal R, Deep G. Exosomes secreted under hypoxia enhance invasiveness and stemness of prostate cancer cells by targeting adherens junction molecules. Mol Carcinog 2015;54:554-65.

26. Deep G, Panigrahi GK. Hypoxia-induced signaling promotes prostate cancer progression: exosomes role as messenger of hypoxic response in tumor microenvironment. Crit Rev Oncog 2015;20:419-34.

27. Fraga A, Ribeiro R, Prnicipe P, Lopes C, Medeiros R. Hypoxia and prostate cancer aggressiveness: a tale with many endings. Clin Genitourin Cancer 2015;13:295-301.

28. Stewart GD, Ross JA, McLaren DB, Parker CC, Habib FK, Riddick ACP. The relevance of a hypoxic tumour microenvironment in prostate cancer. BJU Int 2010;105:8-13.

29. Paolicchi E, Gemignani F, Krstic-Demonacos M, Dedhar S, Mutti L, Landi S. Targeting hypoxic response for cancer therapy. Oncotarget 2016;7:13464-78.

30. Wigerup C, Pahlman S, Bexell D. Therapeutic targeting of hypoxia and hypoxia-inducible factors in cancer. Pharmacol Ther 2016;164:152-69.

31. Hunter FW, Wouters BG, Wilson WR. Hypoxia-activated prodrugs: paths forward in the era of personalised medicine. $\mathrm{Br} J$ Cancer 2016;114:1071-7.

32. Phillips RM. Targeting the hypoxic fraction of tumours using hypoxiaactivated prodrugs. Cancer Chemother Pharmacol 2016;77:441-57.

33. Wilson WR, Hay MP. Targeting hypoxia in cancer therapy. Nat Rev Cancer 2011;11:393-410.

34. Bennewith KL, Dedhar S. Targeting hypoxic tumour cells to overcome metastasis. BMC Cancer 2011;11:504.

35. Albertella MR, Loadman PM, Jones PH, Phillips RM, Rarnpling R, Burnet N, Alcock C, Anthoney A, Vjaters E, Dunk CR, Harris PA, Wong A, Lalani AS, Twelves CJ. Hypoxia-selective targeting by the bioreductive prodrug $\mathrm{AQ} 4 \mathrm{~N}$ in patients with solid tumors: results of a phase I study. Clin Cancer Res 2008;14:1096-104.

36. Patterson LH. Rationale for the use of aliphatic N-Oxides of cytotoxic anthraquinones as prodrug DNA-binding agents - a new class of bioreductive agent. Cancer Metastasis Rev 1993;12:11934.

37. Raleigh SM, Wanogho E, Burke MD, McKeown SR, Patterson LH. Involvement of human cytochromes $\mathrm{P} 450$ (CYP) in the reductive metabolism of AQ4N, a hypoxia activated anthraquinone di-N-oxide prodrug. Int J Radiat Oncol Biol Phys 1998;42:763-7.

38. McCarthy HO, Yakkundi A, McErlane V, Hughes CM, Keilty G, Murray M, Patterson LH, Hirst DG, McKeown SR, Robson T. Bioreductive GDEPT using cytochrome P450 3A4 in combination with AQ4N. Cancer Gene Ther 2003;10:40-8.

39. McErlane V, Yakkundi A, McCarthy HO, Hughes CM, Patterson LH, Hirst DG, Robson T, McKeown SR. A cytochrome P4502B6 meditated gene therapy strategy to enhance the effects of radiation or cyclophosphamide when combined with the bioreductive drug AQ4N. J Gene Med 2005;7:851-9.

40. Yakkundi A, McErlane V, Murray M, McCarthy HO, Ward C, Hughes CM, Patterson LH, Hirst DG, McKeown SR, Robson T. Tumorselective drug activation: a GDEPT approach utilizing cytochrome P450 1A1 and AQ4N. Cancer Gene Ther 2006;13:598-605.

41. Nishida CR, Lee M, de Montellano PRO. Efficient hypoxic activation of the anticancer agent AQ4N by CYP2S1 and CYP2W1. Mol Pharmacol 2010;78:497-502.

42. Saggar JK, Tannock IF. Activity of the hypoxia- activated pro- drug TH-302 in hypoxic and perivascular regions of solid tumors and its potential to enhance therapeutic effects of chemotherapy. Int $J$ Cancer 2014;134:2726-34.

43. DiSilvestro PA, Ali S, Craighead PS, Lucci JA, Lee YC, Cohn DE, Spirtos NM, Tewari KS, Muller C, Gajewski WH, Steinhoff MM, Monk BJ. Phase III randomized trial of weekly cisplatin and irradiation versus cisplatin and tirapazamine and irradiation in Stages IB2, IIA, IIB, IIIB, and IVA cervical carcinoma limited to the pelvis: a gynecologic oncology group study. J Clin Oncol 2014;32:458-U81.

44. Steward WP, Middleton M, Benghiat A, Loadman PM, Hayward C, Waller S, Ford S, Halbert G, Patterson LH, Talbot D. The use of pharmacokinetic and pharmacodynamic end points to determine the dose of AQ4N, a novel hypoxic cell cytotoxin, given with fractionated radiotherapy in a phase I study. Ann Oncol 2007;18:1098-103.

45. Wu M, Wang X, McGregor N, Pienta KJ, Zhang J. Dynamic regulation of Rad51 by E2F1 and p53 in prostate cancer cells upon drug-induced DNA damage under hypoxia. Mol Pharmacol 2014;85:866-76

46. Gu Y, Patterson AV, Atwell GJ, Chernikova SB, Brown JM, Thompson LH, Wilson WR. Roles of DNA repair and reductase activity in the cytotoxicity of the hypoxia-activated dinitrobenzamide mustard PR-104A. Mol Cancer Ther 2009;8:1714-23.

47. Evans JW, Chernikova SB, Kachnic LA, Banath JP, Sordet O, Delahoussaye YM, Treszezamsky A, Chon BH, Feng Z, Gu Y, Wilson WR, Pommier Y, Olive PL, Powell SN, Brown JM. Homologous recombination is the principal pathway for the repair of DNA damage induced by tirapazamine in mammalian cells. Cancer Res 2008;68:257-65.

48. Olcina M, Lecane PS, Hammond EM. Targeting hypoxic cells through the DNA damage response. Clin Cancer Res 2010;16:56249.

49. Lindquist KE, Cran JD, Kordic K, Kyle AH, Minchinton AI. Sensitization of hypoxic cells to ionising radiation by a hypoxia 
activated inhibitor of DNA dependent protein kinase. EJC Supplements 2010;8:161-2.

50. Gani C, Coackley C, Kumareswaran R, Schutze C, Krause M, Zafarana G, Bristow RG. In vivo studies of the PARP inhibitor, AZD2281 , in combination with fractionated radiotherapy: an exploration of the therapeutic ratio. Radiother Oncol 2015;116:486-94.

51. Jiang Y, Verbiest T, Devery AM, Bokobza SM, Weber AM, Leszczynska KB, Hammond EM, Ryan AJ. Hypoxia potentiates the radiation-sensitizing effect of olaparib in human non-small cell lung cancer xenografts by contextual synthetic lethality. Int J Radiat Oncol Biol Phys 2016;95:772-81.

52. Mistry IN, Thomas M, Calder EDD, Conway SJ, Hammond EM. Clinical advances of hypoxia-activated prodrugs in combination with radiation therapy. Int J Radiat Oncol Biol Phys 2017;98:1183-96.

53. Barreto-Andrade JC, Efimova EV, Mauceri HJ, Beckett MA, Sutton HG, Darga TE, Vokes EE, Posner MC, Kron SJ, Weichselbaum RR. Response of human prostate cancer cells and tumors to combining PARP inhibition with ionizing radiation. Mol Cancer Ther 2011;10:1185-93.

54. Patterson LH. Bioreductively activated antitumor N-oxides: the case of AQ4N, a unique approach to hypoxia-activated cancer chemotherapy. Drug Metab Rev 2002;34:581-92.

55. Nesbitt H, Byrne NM, Williams SN, Ming L, Worthington J, Errington RJ, Patterson LH, Smith PJ, McKeown SR, McKenna DJ. Targeting hypoxic prostate tumors using the novel hypoxia-activated prodrug OCT1002 inhibits expression of genes associated with malignant progression. Clin Cancer Res 2017;23:1797-808.

56. Pors K, Shnyder SD, Teesdale-Spittle PH, Hartley JA, Zloh M, Searcey M, Patterson LH. Synthesis of DNA-directed pyrrolidinyl and piperidinyl confined alkylating chloroalkylaminoanthraquinones: Potential for development of tumor-selective N-oxides. J Med Chem 2006;49:7013-23.

57. Ming L, Byrne NM, Camac SN, Mitchell CA, Ward C, Waugh DJ, McKeown SR, Worthington J. Androgen deprivation results in timedependent hypoxia in LNCaP prostate tumours: Informed scheduling of the bioreductive drug AQ4N improves treatment response. Int $J$ Cancer 2013;132:1323-32.

58. Wade D. Deuterium isotope effects on noncovalent interactions between molecules. Chem Biol Interact 1999;117:191-217.

59. Alonzi R, Padhani AR, Taylor NJ, Collins DJ, D’Arcy JA, Stirling JJ, Saunders MI, Hoskin PJ. Antivascular effects of neoadjuvant androgen deprivation for prostate cancer: an in vivo human study using susceptibility and relaxivity dynamic MRI. Int J Radiat Oncol Biol Phys 2011;80:721-7.

60. Milosevic M, Chung P, Parker C, Bristow R, Toi A, Panzarella T, Warde P, Catton C, Menard C, Bayley A, Gospodarowicz M, Hill R. Androgen withdrawal in patients reduces prostate cancer hypoxia: Implications for disease progression and radiation response. Cancer Res 2007;67:6022-5.

61. Sweeney CJ, Chen YH, Carducci M, Liu G, Jarrard DF, Eisenberger M, Wong YN, Hahn N, Kohli M, Cooney MM, Dreicer R, Vogelzang NJ, Picus J, Shevrin D, Hussain M, Garcia JA, DiPaola RS. Chemohormonal therapy in metastatic hormone-sensitive prostate cancer. N Engl J Med 2015;373:737-46.

62. James ND, Sydes MR, Clarke NW, Mason MD, Dearnaley DP, Spears MR, Ritchie AWS, Parker CC, Russell JM, Attard G, de Bono J, Cross W, Jones RJ, Thalmann G, Amos C, Matheson D, Millman R, Alzouebi M, Beesley S, Birtle AJ, Brock S, Cathomas R, Chakraborti P, Chowdhury S, Cook A, Elliott T, Gale J, Gibbs S, Graham JD, Hetherington J, Hughes R, Laing R, McKinna F, McLaren DB,
O'Sullivan JM, Parikh O, Peedell C, Protheroe A, Robinson AJ, Srihari N, Srinivasan R, Staffurth J, Sundar S, Tolan S, Tsang D, Wagstaff J, Parmar MK; STAMPEDE investigators. Addition of docetaxel, zoledronic acid, or both to first-line long-term hormone therapy in prostate cancer (STAMPEDE): survival results from an adaptive, multiarm, multistage, platform randomised controlled trial. Lancet 2016;387:1163-77.

63. Li F, Joergensen JT, Hansen AE, Kjaer A. Kinetic modeling in PET imaging of hypoxia. Am J Nucl Med Mol Imaging 2014;4:490-506.

64. White NS, Errington RJ. Fluorescence techniques for drug delivery research: theory and practice. Adv Drug Deliv Rev 2005;57:17-42.

65. Errington RJ, Ameer-Beg SM, Vojnovic B, Patterson LH, Zloh M, Smith PJ. Advanced microscopy solutions for monitoring the kinetics and dynamics of drug-DNA targeting in living cells. Adv Drug Deliv Rev 2005;57:153-67.

66. Feng L, Cheng L, Dong Z, Tao D, Barnhart TE, Cai W, Chen M, Liu Z. Theranostic liposomes with hypoxia-activated prodrug to effectively destruct hypoxic tumors post-photodynamic therapy. ACS Nano 2017; 11:927-37.

67. Williams KJ, Albertella MR, Fitzpatrick B, Loadman PM, Shnyder SD, Chinje EC, Telfer BA, Dunk CR, Harris PA, Stratford IJ. In vivo activation of the hypoxia-targeted cytotoxin AQ4N in human tumor xenografts. Mol Cancer Ther 2009;8:3266-75.

68. Yang KS, Kohler RH, Landon M, Giedt R, Weissleder R. Single cell resolution in vivo imaging of DNA damage following PARP inhibition. Sci Rep 2015;5:10129.

69. Polanski R, Vincent J, Polanska UM, Petreus T, Tang EK. Caspase-8 activation by TRAIL monotherapy predicts responses to IAPi and TRAIL combination treatment in breast cancer cell lines. Cell Death Dis 2015;6:e1893.

70. Fricke T, Mart RJ, Watkins CL, Wiltshire M, Errington RJ, Smith PJ, Jones AT, Allemann RK. Chemical synthesis of cell-permeable apoptotic peptides from in vivo produced proteins. Bioconjug Chem 2011;22:1763-7.

71. Mart RJ, Errington RJ, Watkins CL, Chappell SC, Wiltshire M, Jones AT, Smith PJ, Allemann RK. BH3 helix-derived biophotonic nanoswitches regulate cytochrome c release in permeabilised cells. Mol Biosyst 2013;9:2597-603.

72. Del Gaizo Moore V, Letai A. BH3 profiling--measuring integrated function of the mitochondrial apoptotic pathway to predict cell fate decisions. Cancer Lett 2013;332:202-5.

73. Abeshouse A, Ahn J, Akbani R, Ally A, Amin S, Andry CD, Annala M, Aprikian A, Armenia J, Arora A, Auman JT, Balasundaram M, Balu S, Barbieri CE, Bauer T, Benz CC, Bergeron A, Beroukhim R, Berrios M, Bivol A, Bodenheimer T, Boice L, Bootwalla MS, dos Reis RB, Boutros PC, Bowen J, Bowlby R, Boyd J, Bradley RK, Breggia A, Brimo F, Bristow CA, Brooks D, Broom BM, Bryce AH, Bubley G, Burks E, Butterfield YSN, Button M, Canes D, Carlotti CG, Carlsen R, Carmel M, Carroll PR, Carter SL, Cartun R, Carver BS, Chan JM, Chang MT, Chen Y, Cherniack AD, Chevalier S, Chin L, Cho J, Chu A, Chuah E, Chudamani S, Cibulskis K, Ciriello G, Clarke A, Cooperberg MR, Corcoran NM, Costello AJ, Cowan J, Crain D, Curley E, David K, Demchok JA, Demichelis F, Dhalla N, Dhir R, Doueik A, Drake B, Dvinge H, Dyakova N, Felau I, Ferguson ML, Frazer S, Freedland S, Fu Y, Gabriel SB, Gao JJ, Gardner J, GastierFoster JM, Gehlenborg N, Gerken M, Gerstein MB, Getz G, Godwin AK, Gopalan A, Graefen M, Graim K, Gribbin T, Guin R, Gupta M, Hadjipanayis A, Haider S, Hamel L, Hayes DN, Heiman DI, Hess J, Hoadley KA, Holbrook AH, Holt RA, Holway A, Hovens CM, Hoyle AP, Huang M, Hutter CM, Ittmann M, Iype L, Jefferys SR, Jones 
CD, Jones SJM, Juhl H, Kahles A, Kane CJ, Kasaian K, Kerger M, Khurana E, Kim J, Klein RJ, Kucherlapati R, Lacombe L, Ladanyi M, Lai PH, Laird PW, Lander ES, Latour M, Lawrence MS, Lau K, LeBien T, Lee D, Lee S, Lehmann KV, Leraas KM, Leshchiner I, Leung R, Libertino JA, Lichtenberg TM, Lin P, Linehan WM, Ling S, Lippman SM, Liu J, Liu W, Lochovsky L, Loda M, Logothetis C, Lolla L, Longacre T, Lu YL, Luo JH, Ma Y, Mahadeshwar HS, Mallery D, Mariamidze A, Marra MA, Mayo M, McCall S, McKercher G, Meng S, Mes-Masson AM, Merino MJ, Meyersson M, Mieczkowski PA, Mills GB, Shaw KRM, Minner S, Moinzadeh A, Moore RA, Morris S, Morrison C, Mose LE, Mungall AJ, Murray BA, Myers JB, Naresh R, Nelson J, Nelson MA, Nelson PS, Newton Y, Noble MS, Noushmehr H, Nykter M, Pantazi A, Parfenov M, Park PJ, Parker JS, Paulauskis J, Penny R, Perou CM, Piche A, Pihl T, Pinto PA, Prandi D, Protopopov A, Ramirez NC, Rao A, Rathmell WK, Ratsch G, Ren XJ, Reuter VE, Reynolds SM, Rhie SK, RiegerChrist K, Roach J, Robertson AG, Robinson B, Rubin MA, Saad F, Sadeghi S, Saksena G, Saller C, Salner A, Sanchez-Vega F, Sander C, Sandusky G, Sauter G, Sboner A, Scardino PT, Scarlata E, Schein JE, Schlomm T, Schmidt LS, Schultz N, Schumacher SE, Seidman J, Neder L, Seth S, Sharp A, Shelton C, Shelton T, Shen H, Shen RL, Sherman M, Sheth M, Shi Y, Shih J, Shmulevich I, Simko J, Simon R, Simons JV, Sipahimalani P, Skelly T, Sofia HJ, Soloway MG, Song XZ, Sorcini A, Sougnez C, Stepa S, Stewart C, Stewart J, Stuart JM, Sullivan TB, Sun C, Sun HD, Tam A, Tan DH, Tang JB, Tarnuzzer R, Tarvin K, Taylor BS, Teebagy P, Tenggara I, Tetu B, Tewari A, Thiessen N, Thompson T, Thorne LB, Tirapelli DP, Tomlins SA, Trevisan FA, Troncoso P, True LD, Tsourlakis MC, Tyekucheva S, Van Allen E, Van den Berg DJ, Veluvolu U, Verhaak R, Vocke CD, Voet D, Wan YH, Wang QG, Wang WY, Wang ZN, Weinhold N, Weinstein JN, Weisenberger DJ, Wilkerson MD, Wise L, Witte J, Wu CC, Wu JY, Wu Y, Xu AW, Yadav SS, Yang LM, Yang LX, Yau C, Ye HH, Yena P, Zeng T, Zenklusen JC, Zhang HL, Zhang JH, Zhang JS, Zhang W, Zhong Y, Zhu K, Zmuda E; Cancer Genome Atlas Research Network. The molecular taxonomy of primary prostate cancer. Cell 2015;163:1011-25.

74. Ciccarese C, Santoni M, Brunelli M, Buti S, Modena A, Nabissi M, Artibani W, Martignoni G, Montironi R, Tortora G, Massari F. AR-V7 and prostate cancer: the watershed for treatment selection? Cancer Treat Rev 2016;43:27-35.

75. Buffa FM, Harris AL, West CM, Miller CJ. Large meta-analysis of multiple cancers reveals a common, compact and highly prognostic hypoxia metagene. Br J Cancer 2010;102:428-35.

76. Winter SC, Buffa FM, Silva P, Miller C, Valentine HR, Turley H, Shah KA, Cox GJ, Corbridge RJ, Homer JJ, Musgrove B, Slevin N, Sloan P, Price P, West CML, Harris AL. Relation of a hypoxia metagene derived from head and neck cancer to prognosis of multiple cancers. Cancer Res 2007;67:3441-9.

77. Eustace A, Mani N, Span PN, Irlam JJ, Taylor J, Betts GN, Denley H, Miller CJ, Homer JJ, Rojas AM, Hoskin PJ, Buffa FM, Harris AL, Kaanders JH, West CM. A 26-gene hypoxia signature predicts benefit from hypoxia-modifying therapy in laryngeal cancer but not bladder cancer. Clin Cancer Res 2013;19:4879-88.

78. Lalonde E, Ishkanian AS, Sykes J, Fraser M, Ross-Adams H, Erho N, Dunning MJ, Halim S, Lamb AD, Moon NC, Zafarana G, Warren AY, Meng XY, Thoms J, Grzadkowski MR, Berlin A, Have CL, Ramnarine VR, Yao CQ, Malloff CA, Lam LL, Xie HL, Harding NJ, Mak DYF, Chu KC, Chong LC, Sendorek DH, P'ng C, Collins CC, Squire JA, Jurisica I, Cooper C, Eeles R, Pintilie M, Dal Pra A, Davicioni E, Lam WL, Milosevic M, Neal DE, van der Kwast T,
Boutros PC, Bristow RG. Tumour genomic and microenvironmental heterogeneity for integrated prediction of 5-year biochemical recurrence of prostate cancer: a retrospective cohort study. Lancet Oncol 2014; 15:1521-32.

79. Ragnum HB, Vlatkovic L, Lie AK, Axcrona K, Julin CH, Frikstad KM, Hole KH, Seierstad T, Lyng H. The tumour hypoxia marker pimonidazole reflects a transcriptional programme associated with aggressive prostate cancer. Br J Cancer 2015;112:382-90.

80. Luu HN, Lin HY, Sorensen KD, Ogunwobi OO, Kumar N, Chornokur G, Phelan C, Jones D, Kidd L, Batra J, Yamoah K, Berglund A, Rounbehler RJ, Yang M, Lee SH, Kang N, Kim SJ, Park JY, Di Pietro G. miRNAs associated with prostate cancer risk and progression. BMC Urol 2017;17.

81. Lynch SM, O’Neill KM, McKenna MM, Walsh CP, McKenna DJ. Regulation of miR-200c and miR-141 by methylation in prostate cancer. Prostate 2016;76:1146-59.

82. Dang K, Myers KA. The role of hypoxia-induced miR-210 in cancer progression. Int J Mol Sci 2015;16:6353-72.

83. Huang X, Le QT, Giaccia AJ. MiR-210-micromanager of the hypoxia pathway. Trends Mol Med 2010;16:230-7.

84. Taddei ML, Cavallini L, Comito G, Giannoni E, Folini M, Marini A, Gandellini P, Morandi A, Pintus G, Raspollini MR, Zaffaroni N, Chiarugi P. Senescent stroma promotes prostate cancer progression: the role of miR-210. Mol Oncol 2014;8:1729-46.

85. Haldrup C, Kosaka N, Ochiya T, Borre M, Hoyer S, Orntoft TF, Sorensen KD. Profiling of circulating microRNAs for prostate cancer biomarker discovery. Drug Deliv Transl Res 2014;4:19-30.

86. Cheng HH, Mitchell PS, Kroh EM, Dowell AE, Chery L, Siddiqui J, Nelson PS, Vessella RL, Knudsen BS, Chinnaiyan AM, Pienta KJ, Morrissey C, Tewari M. Circulating microRNA profiling identifies a subset of metastatic prostate cancer patients with evidence of cancerassociated hypoxia. PLoS One 2013;8:e69239.

87. Mateo J, Carreira S, Sandhu S, Miranda S, Mossop H, Perez-Lopez R, Rodrigues DN, Robinson D, Omlin A, Tunariu N, Boysen G, Porta N, Flohr P, Gillman A, Figueiredo I, Paulding C, Seed G, Jain S, Ralph C, Protheroe A, Hussain S, Jones R, Elliott T, McGovern U, Bianchini D, Goodall J, Zafeiriou Z, Williamson CT, Ferraldeschi R, Riisnaes R, Ebbs B, Fowler G, Roda D, Yuan W, Wu YM, Cao X, Brough R, Pemberton H, A'Hern R, Swain A, Kunju LP, Eeles R, Attard G, Lord CJ, Ashworth A, Rubin MA, Knudsen KE, Feng FY, Chinnaiyan AM, Hall E, de Bono JS. DNA-repair defects and olaparib in metastatic prostate cancer. N Engl J Med 2015;373:1697-708.

88. Nordsmark M, Bentzen SM, Overgaard J. Measurement of human tumour oxygenation status by a polarographic needle electrode. An analysis of inter- and intratumour heterogeneity. Acta Oncol 1994;33:383-9.

89. Becker A, Hansgen G, Bloching M, Weigel C, Lautenschlager C, Dunst J. Oxygenation of squamous cell carcinoma of the head and neck: comparison of primary tumors, neck node metastases, and normal tissue. Int J Radiat Oncol Biol Phys 1998;42:35-41.

90. Le QT, Kovacs MS, Dorie MJ, Koong A, Terris DJ, Pinto HA, Goffinet DR, Nowels K, Bloch D, Brown JM. Comparison of the comet assay and the oxygen microelectrode for measuring tumor oxygenation in head-and-neck cancer patients. Int $J$ Radiat Oncol Biol Phys 2003;56:375-83.

91. Falk SJ, Ward R, Bleehen NM. The influence of carbogen breathing on tumour tissue oxygenation in man evaluated by computerised p02 histography. Br J Cancer 1992;66:919-24.

92. Le QT, Chen E, Salim A, Cao H, Kong CS, Whyte R, Donington J, Cannon W, Wakelee H, Tibshirani R, Mitchell JD, Richardson 
D, O’Byrne KJ, Koong AC, Giaccia AJ. An evaluation of tumor oxygenation and gene expression in patients with early stage nonsmall cell lung cancers. Clin Cancer Res 2006;12:1507-14.

93. Vaupel P, Mayer A, Briest S, Hockel M. Oxygenation gain factor: a novel parameter characterizing the association between hemoglobin level and the oxygenation status of breast cancers. Cancer Res 2003;63:7634-7.

94. Koong AC, Mehta VK, Le QT, Fisher GA, Terris DJ, Brown JM, Bastidas AJ, Vierra M. Pancreatic tumors show high levels of hypoxia. Int J Radiat Oncol Biol Phys 2000;48:919-22.

95. Graffman S, Bjork P, Ederoth P, Ihse I. Polarographic pO2 measurements of intra-abdominal adenocarcinoma in connection with intraoperative radiotherapy before and after change of oxygen concentration of anaesthetic gases. Acta Oncol 2001;40:105-7.

96. Movsas B, Chapman JD, Hanlon AL, Horwitz EM, Pinover WH, Greenberg RE, Stobbe C, Hanks GE. Hypoxia in human prostate carcinoma: an Eppendorf PO2 study. Am J Clin Oncol 2001;24:45861.

97. Parker C, Milosevic M, Toi A, Sweet J, Panzarella T, Bristow R, Catton C, Catton P, Crook J, Gospodarowicz M, McLean M, Warde P, Hill RP. Polarographic electrode study of tumor oxygenation in clinically localized prostate cancer. Int J Radiat Oncol Biol Phys 2004;58:750-7.

98. Movsas B, Chapman JD, Horwitz EM, Pinover WH, Greenberg RE, Hanlon AL, Iyer R, Hanks GE. Hypoxic regions exist in human prostate carcinoma. Urology 1999;53:11-8.

99. Lartigau E, Randrianarivelo H, Avril MF, Margulis A, Spatz A, Eschwege F, Guichard M. Intratumoral oxygen tension in metastatic melanoma. Melanoma Res 1997;7:400-6.

100. Kallinowski FBH. Can the oxygenation status of rectal carcinomas be improved by hypoxia? In: Vaupel P, Kelleher DK, Günderoth M, editors. Tumor oxygenation. Stuttgart, Germany: Gustav Fischer; 1995. p. 291-6.

101. Mattern J, Kallinowski F, Herfarth C, Volm M. Association of resistance-related protein expression with poor vascularization and low levels of oxygen in human rectal cancer. Int $J$ Cancer 1996;67:20-3.

102. von Pawel J, von Roemeling R, Gatzemeier U, Boyer M, Elisson LO, Clark P, Talbot D, Rey A, Butler TW, Hirsh V, Olver I, Bergman B, Ayoub J, Richrdson G, Dunlop D, Arcenas A, Vescio R, Viallet J, Treat J. Tirapazamine plus cisplatin versus cisplatin in advanced nonsmall-cell lung cancer: a report of the international CATAPULT I study group. J Clin Oncol 2000;18:1351-9.

103. Marcu L, Olver I. Tirapazamine: from bench to clinical trials. Curr Clin Pharmacol 2006;1:71-9.

104. Phillips RM, Hendriks HR, Peters GJ, Grp E-PMM. EO9
(Apaziquone): from the clinic to the laboratory and back again. $\mathrm{Br} J$ Pharmacol 2013;168:11-8.

105. Hendricksen K, Cornel EB, de Reijke TM, Arentsen HC, Chawla $\mathrm{S}$, Witjes JA. Phase 2 study of adjuvant intravesical instillations of apaziquone for high risk nonmuscle invasive bladder cancer. $J$ Urol 2012;187:1195-9.

106. Meng FY, Evans JW, Bhupathi D, Banica M, Lan L, Lorente G, Duan JX, Cai XH, Mowday AM, Guise CP, Maroz A, Anderson RF, Patterson AV, Stachelek GC, Glazer PM, Matteucci MD, Hart CP. Molecular and cellular pharmacology of the hypoxia-activated prodrug TH-302. Mol Cancer Ther 2012;11:740-51.

107. Riedel RF, Meadows KL, Lee PH, Morse MA, Uronis HE, Blobe GC, George DJ, Crawford J, Niedzwiecki D, Rushing CN, Arrowood CC, Hurwitz HI. Phase I study of pazopanib plus TH-302 in advanced solid tumors. Cancer Chemother Pharmacol 2017;79:611-9.

108. Badar T, Handisides DR, Benito JM, Richie MA, Borthakur G, Jabbour E, Harutyunyan K, Konoplev S, Faderl S, Kroll S, Andreeff M, Pearce T, Kantarjian HM, Cortes JE, Thomas DA, Konopleva M. Phase I study of evofosfamide, an investigational hypoxiaactivated prodrug, in patients with advanced leukemia. Am J Hematol 2016;91:800-5.

109. Patterson AV, Silva S, Guise C, Bull M, Abbattista M, Hsu A, Sun JD, Hart CP, Pearce TE, Smaill JB. TH-4000, a hypoxia-activated EGFR/Her2 inhibitor to treat EGFR-TKI resistant T790M-negative NSCLC. J Clin Oncol 2015;33:e13548.

110. Guise CP, Mowday AM, Ashoorzadeh A, Yuan R, Lin WH, Wu DH, Smaill JB, Patterson AV, Ding K. Bioreductive prodrugs as cancer therapeutics: targeting tumor hypoxia. Chin J Cancer 2014;33:80-6.

111. McKeage MJ, Jameson MB, Ramanathan RK, Rajendran J, Gu YC, Wilson WR, Melink TJ, Tchekmedyian NS. PR-104 a bioreductive pre-prodrug combined with gemcitabine or docetaxel in a phase Ib study of patients with advanced solid tumours. BMC Cancer 2012;12:496.

112. Haffty BG, Wilson LD, Son YH, Cho EI, Papac RJ, Fischer DB, Rockwell S, Sartorelli AC, Ross DA, Sasaki CT, Fischer JJ. Concurrent chemo-radiotherapy with mitomycin $\mathrm{C}$ compared with porfiromycin in squamous cell cancer of the head and neck: final results of a randomized clinical trial. Int J Radiat Oncol Biol Phys 2005;61:119-28.

113. Panettiere FJ, Talley RW, Torres J, Lane M. Porfiromycin in management of epidermoid and transitional cell-cancer - phase II study. Cancer Treat Rep 1976;60:907-11.

114. Danson SJ, Johnson P, Ward TH, Dawson M, Denneny O, Dickinson G, Aarons L, Watson A, Jowle D, Cummings J, Robson L, Halbert G, Dive C, Ranson M. Phase I pharmacokinetic and pharmacodynamic study of the bioreductive drug RH1. Cancer Treat Rep 2011;22:1653-60. 